ACTA AGROBOTANICA

Vol. 58, z. 12005

s. 185191

\title{
Effects of some growing media on the growth of strawberry cvs. 'Camarosa' and 'Fern'
}

\section{SEZAI ERCISLI ${ }^{*}{ }^{*}$ USTUN SAHIN $^{2}$ AHMET ESITKEN ${ }^{1}$ OMER ANAPALI ${ }^{2}$}

\author{
Atatürk University, Faculty of Agriculture, Department of Horticulture, Erzurum \\ TURKEY \\ Atatürk Univ., Fac. of Agric., Dept. of Agric. Structures and Irrigation, Erzurum \\ TURKEY \\ *: Corresponding author (sercisli@atauni.edu.tr)
}

(Received: 13.04.2004)

\section{Sum mary}

This study evaluated the development of above and under ground parts of strawberry plants cvs. 'Fern' and 'Camarosa ' in a glasshouse using perlite, forest soil, finpeat, peat, finpeat+perlite $(1: 1)$ and peat+perlite (1:1) as substrates. The effects of different growing media on development of above and under ground parts of plant were statistically significant. The highest number of primary roots per plant, length of the most developed roots and number of crowns per runner were obtained from perlite, finpeat+perlite and peat medium, respectively, in both cultivars. The runner length, number of runners per plant, leaf area, fresh root weight and dry root weight varied between cultivars according to growth medium. In general peat, finpeat or finpeat+perlite gave the best results in terms of above and under ground parts of plants in both cultivars.

Some important properties such as water retention capacity, cation exchangeable capacity, $\mathrm{pH}$, porosity etc. of growing media using in this study were also determined.

Key words: Strawberry, growing media, plant growth

\section{INTRODUCTION}

The cultivated strawberry, Fragaria $x$ ananassa, is a regular part of the diets of millions of people. Known for its delicate flavor and rich vitamin content, strawberries are cultivated in all arable regions of the globe from the Arctic to the Tropics (Hancock, 1999). 
The difficulty and cost of controlling soilborn pests and diseases, soil salinity, lack of fertile soil, water shortage, lack of space etc., have led to the development of substrates for soilless cultivation (Oly mpious, 1992). The properties of different materials used as growing media exhibit direct and indirect effects on plant growth and productivity. Some technical and economic factors play role when choosing substrates. At the beginning gravel or sand, later materials such as peat, vermiculite, perlite have been used commonly (Çelikel, 1999). Today, in many countries, soilless culture techniques are used for production especially in greenhouses.

Strawberry production in Turkey has steadily increased from $400 \mathrm{t}$ in 1968, to $50000 \mathrm{t}$ in 1989 and $120000 \mathrm{t}$ in 1998. In Turkey, strawberry cultivation is generally done in open field or walk-in plastic tunnels to provide earliness. There is a big demand for greenhouse strawberry production, during the recent years to extend the harvest period. The cultivation of strawberries in greenhouses in Turkey has also expended increasingly specially in the Mediterranean Area in the last few decades. But, in the Mediterranean Region of Turkey, greenhouse strawberry growing without crop rotation for many years in the same soil has resulted some soil-borne problems. For this reason, soil disinfection is a common practice in strawberry production, even in open fields. Soil disinfection is made by using chemicals, especially methylbromide. Due to the bromine residues in soil, underground water and crops, methylbromide is banned in soil disinfection or minimized in many countries (Jensen and Collins, 1985; B e noit, 1989). Since soil in greenhouse production has more problems due to being under cover and due to monoculture, soilless cultivation of strawberries provides an important advantage by avoiding the need to sterilize the greenhouse soil (Ozeker et al., 1999). On the other hand, there is also a big demand for healthy strawberry seedlings in Turkey because of increased production. Few experiments have been conducted with soilless culture for strawberry growth, yield and runner plants growth on soilless culture.

The purpose of this study was to determine the suitability of different materials on runner plants development of strawberry cvs. 'Fern' and 'Camarosa '.

\section{MATERIALS AND METHODS}

Strawberry (cvs. 'Fern' and 'Camarosa') plants were planted directly in five liter plastic bags filled with different growing media. The growing media compared in the trial were:

1 Forest Soil

2 Peat+Perlite (1:1)

3 Peat
4 Finpeat

5 Perlite

6 Finpeat+Perlite (1:1)

Plants were irrigated as required without any limitation of water. The amount of moisture the substrates retained in different tensions was determined a pressure 
membrane (Demiralay, 1993). Plants were planted on 10 May, 2000 and plastic bags were kept under greenhouse temperature regime of $25 / 20{ }^{\circ} \mathrm{C}$ day/night, respectively.

The daily nutrient solution was prepared according to D a y (1991). After 6 months growing period, each plant was uprooted and evaluated in terms of final weight, increase of fresh weight, runner length, number of runner per plant, number of crowns per plant, number of crowns per runner, leaf area, fresh root weight, dry root weight, length of the most developed roots and number of primary roots per plant.

The experiment design was of a completely randomized design with five replicates and each replication had 5 plants. Data were subjected to analysis of variance and the means were compared according to Duncan's test.

\section{RESULTS}

\section{The amount of moisture (Pv) and pore size distribution (\%) of media}

The amount of moisture retained in different tensions $(\mathrm{Pv})$ and pore size distribution (\%) of the substrates are given in Table 1 . The best medium in terms of higher moisture retained capacity at lower tensions $(<0.33 \mathrm{~atm})$ was finpeat $(57.1 \%)$, which was followed by peat+perlite $(57.0 \%)$ and perlite $(53.7 \%)$. Amount of larger pore size distribution ( $>100$ ěm) providing aeration and drainage was the highest in finpeat (50.9 $\%$ ) followed by peat $(44.6 \%)$ (Table 1$)$.

Table 1

The amount of moisture retained in different tensions $(\mathrm{Pv})$ and pore size distribution $(\%)$ of substrates

\begin{tabular}{|l|c|c|c|c|c|c|c|c|}
\hline \multirow{2}{*}{ Substrates } & \multicolumn{3}{|c|}{ Moisture tension (atm) } & \multicolumn{4}{c|}{ Pore size $(\mu \mathrm{m})$} \\
\cline { 2 - 10 } & 00.01 & 0.010 .1 & 0.10 .33 & 0.3315 & $>100$ & 10030 & 303 & $<3$ \\
\hline Finpeat & 45.4 & 10.3 & 1.4 & 6.0 & 50.9 & 4.8 & 5.5 & 17.9 \\
\hline Finpeat+Perlite & 34.5 & 13.5 & 1.7 & 3.8 & 43.2 & 4.8 & 4.4 & 16.8 \\
\hline Peat & 39.1 & 8.5 & 3.7 & 12.3 & 44.6 & 3.0 & 11.9 & 19.7 \\
\hline Peat+Perlite & 35.0 & 14.7 & 7.3 & 6.5 & 43.0 & 6.7 & 11.0 & 14.5 \\
\hline Perlite & 31.3 & 16.8 & 5.6 & 3.5 & 40.8 & 7.3 & 7.5 & 14.0 \\
\hline Forest Soil & 15.3 & 10.2 & 5.0 & 11.9 & 21.5 & 4.0 & 10.6 & 18.4 \\
\hline
\end{tabular}




\section{Final weight}

The highest final weight was obtained from peat medium in both cultivars as a $169.64 \mathrm{~g}$ for cv. 'Fern' and $166.97 \mathrm{~g}$ for cv. 'Camarosa'. Both cultivars grown in forest soil had the least final weight.

\section{Runner length}

The effects of growth media on runner length in both cultivars were statistically significant $(\mathrm{p}<0.01)$. The highest runner length was obtained from finpeat medium in cv. 'Fern' $(183.41 \mathrm{~cm})$ but in peat medium in cv. 'Camarosa' $(185.22 \mathrm{~cm})$. However, peat+perlite medium gave the lowest values in terms of runner length for both cultivars.

\section{Number of runners per plant}

Growth medium statistically affected number of runners per plant in both 'Fern' and 'Camarosa' cultivars. The highest number of runners per plant was obtained from peat for 'Fern' cultivar as a 6.48, while from finpeat+perlite in 'Camarosa' cultivar as a 7.62 .

\section{Number of crowns per runner}

Growth media varied in terms of number of crowns per runner for both 'Fern' and 'Camarosa' cultivars. The highest number of crowns per runner was found in peat medium for both cultivars as 3.28 for cv. 'Fern' and 3.86 for cv. 'Camarosa', respectively.

\section{Leaf area}

The highest leaf area was obtained from forest soil in 'Fern' cultivar $\left(80.8 \mathrm{~cm}^{2}\right)$, while on peat medium in 'Camarosa' cultivar $\left(130.9 \mathrm{~cm}^{2}\right)$.

Table 2

The Effect of Growing Media on the Plant Properties of Strawberry cv. 'Fern'

\begin{tabular}{|l|c|c|c|c|c|c|c|}
\hline \multicolumn{1}{|c|}{ Media } & $\begin{array}{c}\text { First } \\
\text { weight } \\
(\mathrm{g})\end{array}$ & $\begin{array}{c}\text { Final } \\
\text { weight } \\
(\mathrm{g})\end{array}$ & $\begin{array}{c}\text { Increase } \\
\text { of fresh } \\
\text { weight } \\
(\%)\end{array}$ & $\begin{array}{c}\text { Runner } \\
\text { lenght } \\
(\mathrm{cm})\end{array}$ & $\begin{array}{c}\text { Number } \\
\text { of } \\
\text { runners } \\
\text { per } \\
\text { plant }\end{array}$ & $\begin{array}{c}\text { Number } \\
\text { of } \\
\text { crowns } \\
\text { per } \\
\text { runner }\end{array}$ & $\begin{array}{c}\text { Leaf } \\
\text { area } \\
\left(\mathrm{cm}^{2}\right)\end{array}$ \\
\hline Forest Soil & 7.83 & $148.01 \mathrm{~b}$ & 1790 & $163.01 \mathrm{~b}$ & $5.20 \mathrm{~b}$ & $2.07 \mathrm{c}$ & $80.8 \mathrm{a}$ \\
Peat+Perlite (1:1) & 8.41 & $162.06 \mathrm{ab}$ & 1827 & $157.62 \mathrm{~b}$ & $5.38 \mathrm{~b}$ & $\begin{array}{c}2.23 \mathrm{bc} \\
51.7 \mathrm{c}\end{array}$ \\
Peat & 8.04 & $169.64 \mathrm{a}$ & 2010 & $178.87 \mathrm{a}$ & $6.48 \mathrm{a}$ & $3.28 \mathrm{a}$ & $60.6 \mathrm{bc}$ \\
Finpeat & 7.97 & $167.25 \mathrm{ab}$ & 1998 & $183.41 \mathrm{a}$ & $5.43 \mathrm{~b}$ & $2.41 \mathrm{abc}$ & $69.2 \mathrm{abc}$ \\
Perlite & 7.83 & $157.49 \mathrm{ab}$ & 1911 & $180.62 \mathrm{a}$ & $6.07 \mathrm{ab}$ & $3.22 \mathrm{a}$ & $71.4 \mathrm{ab}$ \\
Finpeat+Perlite (1:1) & 8.12 & $166.76 \mathrm{ab}$ & 1954 & $179.22 \mathrm{a}$ & $5.68 \mathrm{ab}$ & $3.01 \mathrm{ab}$ & $72.2 \mathrm{ab}$ \\
\hline
\end{tabular}


Table 3

The effect of growing media on the plant properties of strawberry cv. 'Camarosa'

\begin{tabular}{|l|c|c|c|c|c|c|c|}
\hline \multicolumn{1}{|c|}{ Media } & $\begin{array}{c}\text { First } \\
\text { weight } \\
(\mathrm{g})\end{array}$ & $\begin{array}{c}\text { Final } \\
\text { weight } \\
(\mathrm{g})\end{array}$ & $\begin{array}{c}\text { Increase } \\
\text { of fresh } \\
\text { weight } \\
(\%)\end{array}$ & $\begin{array}{c}\text { Runner } \\
\text { lenght } \\
(\mathrm{cm})\end{array}$ & $\begin{array}{c}\text { Number } \\
\text { of } \\
\text { runners } \\
\text { per } \\
\text { plant }\end{array}$ & $\begin{array}{c}\text { Number } \\
\text { of } \\
\text { crowns } \\
\text { per } \\
\text { runner }\end{array}$ & $\begin{array}{c}\text { Leaf } \\
\text { area } \\
\left(\mathrm{cm}^{2}\right)\end{array}$ \\
\hline Forest Soil & 7.39 & $156.87 \mathrm{~b}$ & 2023 & $164.41 \mathrm{bc}$ & $7.41 \mathrm{ab}$ & $3.04 \mathrm{abc}$ & $85.5 \mathrm{~b}$ \\
Peat+Perlite (1:1) & 7.53 & $158.96 \mathrm{ab}$ & 2011 & $163.86 \mathrm{bc}$ & $6.04 \mathrm{~b}$ & $2.43 \mathrm{bc}$ & $103.9 \mathrm{ab}$ \\
Peat & 8.02 & $166.97 \mathrm{ab}$ & 1982 & $185.22 \mathrm{a}$ & $6.61 \mathrm{ab}$ & $3.86 \mathrm{a}$ & $130.9 \mathrm{a}$ \\
Finpeat & 7.91 & $160.43 \mathrm{ab}$ & 1929 & $181.42 \mathrm{ab}$ & $6.82 \mathrm{ab}$ & $2.22 \mathrm{bc}$ & $107.3 \mathrm{ab}$ \\
Perlite & 7.88 & $160.56 \mathrm{ab}$ & 1937 & $161.43 \mathrm{bc}$ & $7.06 \mathrm{ab}$ & $2.06 \mathrm{c}$ & $100.1 \mathrm{~b}$ \\
Finpeat+Perlite (1:1) & 8.10 & $175.92 \mathrm{a}$ & 2072 & $179.66 \mathrm{ab}$ & $7.62 \mathrm{a}$ & $3.48 \mathrm{ab}$ & $104 . \mathrm{ab}$ \\
\hline
\end{tabular}

\section{Number of primary roots per plant}

Number of primary roots per plant was affected by the growing media in both cultivars $(\mathrm{p}<0.01)$. Perlite gave the best results in terms of number of primary roots per plant in both cultivars (30.83 for 'Fern' and 26.82 for 'Camarosa').

\section{Length of the most developed roots}

There were significant differences between growth media with respect to length of the most developed roots in both cultivars. The highest length of the most developed roots was obtained from finpeat + perlite medium in both cultivars as a 49.21 for cv. 'Fern' and 44.42 for 'Camarosa' cultivar, whereas the lowest length of the most developed root was obtained from forest soil in both cultivars.

\section{Fresh root weight}

The results obtained indicated that different growth medium affected the fresh root weight differently. Higher fresh root weight was recorded in cv. 'Fern' grown in finpeat $(25.90 \mathrm{~g})$ and in 'Camarosa' cultivar grown in finpeat + perlite medium $(22.99 \mathrm{~g})$.

\section{Dry root weight}

There were significant effects on dry root weight related to the growth medium. In 'Fern' cultivar, the highest dry root weight was obtained from the plants grown in the peat medium $(8.28 \mathrm{~g})$ and in cv. 'Camarosa' grown in the finpeat medium $(7.71 \mathrm{~g})$. Dry root weight was lower in the forest soil in both cultivars. 
Table 4

The effect of growth mediums on the root properties of strawberry cv. 'Fern'

\begin{tabular}{|l|c|c|c|c|}
\hline \multicolumn{1}{|c|}{ Media } & $\begin{array}{c}\text { Number of } \\
\text { primer roots } \\
\text { per plant }\end{array}$ & $\begin{array}{c}\text { Lenght of the } \\
\text { most } \\
\text { developed } \\
\text { root } \\
(\mathrm{cm})\end{array}$ & $\begin{array}{c}\text { Fresh } \\
\text { root weight } \\
(\mathrm{g})\end{array}$ & $\begin{array}{c}\text { Dry } \\
\text { root weight } \\
(\mathrm{g})\end{array}$ \\
\hline Forest Soil & $18.60 \mathrm{~b}$ & $34.63 \mathrm{c}$ & $11.46 \mathrm{~b}$ & $5.513 \mathrm{~b}$ \\
Peat+Perlite $(1: 1)$ & $24.41 \mathrm{ab}$ & $46.82 \mathrm{a}$ & $18.48 \mathrm{ab}$ & $7.328 \mathrm{ab}$ \\
Peat & $26.22 \mathrm{ab}$ & $37.60 \mathrm{bc}$ & $22.53 \mathrm{ab}$ & $8.286 \mathrm{a}$ \\
Finpeat & $23.61 \mathrm{ab}$ & $41.69 \mathrm{abc}$ & $25.90 \mathrm{a}$ & $7.612 \mathrm{ab}$ \\
Perlite & $30.83 \mathrm{a}$ & $44.08 \mathrm{ab}$ & $16.66 \mathrm{ab}$ & $5.810 \mathrm{ab}$ \\
Finpeat+Perlite $(1: 1)$ & $22.87 \mathrm{ab}$ & $49.21 \mathrm{a}$ & $21.88 \mathrm{ab}$ & $7.586 \mathrm{ab}$ \\
\hline
\end{tabular}

Table 5

The effect of growth mediums on the root properties of strawberry cv. 'Camarosa'

\begin{tabular}{|l|c|c|c|c|}
\hline Media & $\begin{array}{c}\text { Number of } \\
\text { primer roots } \\
\text { per plant }\end{array}$ & $\begin{array}{c}\text { Lenght of the } \\
\text { most } \\
\text { developed } \\
\text { root } \\
(\mathrm{cm})\end{array}$ & $\begin{array}{c}\text { Fresh } \\
\text { root weight } \\
(\mathrm{g})\end{array}$ & $\begin{array}{c}\text { Dry } \\
\text { root weight } \\
(\mathrm{g})\end{array}$ \\
\hline Forest Soil & $13.61 \mathrm{~b}$ & $29.48 \mathrm{c}$ & $8.78 \mathrm{~b}$ & $4.914 \mathrm{~b}$ \\
Peat+Perlite $(1: 1)$ & $23.27 \mathrm{a}$ & $41.26 \mathrm{a}$ & $17.79 \mathrm{ab}$ & $7.555 \mathrm{ab}$ \\
Peat & $19.04 . \mathrm{ab}$ & $32.06 \mathrm{bc}$ & $11.67 \mathrm{~b}$ & $5.861 \mathrm{ab}$ \\
Finpeat & $20.48 \mathrm{ab}$ & $42.44 \mathrm{a}$ & $17.17 \mathrm{ab}$ & $7.716 \mathrm{a}$ \\
Perlite & $26.82 \mathrm{a}$ & $38.63 \mathrm{ab}$ & $15.78 \mathrm{ab}$ & $6.332 \mathrm{ab}$ \\
Finpeat+Perlite $(1: 1)$ & $26.39 \mathrm{a}$ & $44.42 \mathrm{a}$ & $22.99 \mathrm{a}$ & $7.243 \mathrm{ab}$ \\
\hline
\end{tabular}

\section{DISCUSSION}

The results obtained in this research indicated that number of primary roots per plant, length of the most developed roots, fresh root weight, dry root weight, final weight, runner length, number of crowns per runner, number of runners per plant and leaf area of strawberry plants were significantly affected depending on both growth media and cultivars. Strawberry showed different responses to ecological conditions (P a y d a s and Kaska, 1992). In general, the best results, in terms of development of above ground parts of plants were obtained from peat, finpeat, finpeat+perlite media in both cultivars. On the other hand, the root development of cultivars was higher on peat, finpeat or finpeat+perlite media. 
The substrates with which positive responses were obtained were of good aeration and low tension water potentials (Table 1). The growth and development of plants were affected by aeration, organic matter content, $\mathrm{pH}$, temperature and cation exchangeable capacity (Kacar, 1989). As perlite contains no organic matter, finpeat, peat and their mixtures with perlite gave promising results.

\section{REFERENCES}

B en oit F., 1989. Horticultural substrates made of rebounded polyurethane foam. Kuntstoffe German Plastics, 79 (4): 2831.

Ç elikel G., 1999. Effect of different substrates on yield and quality of tomato. Acta Hort., 486: 353357.

Day D., 1991, Growing in perlite. Grower Digest No. 12, Grower Pub. LTD., London, $36 \mathrm{p}$.

Demiralay Ý., 1993. Toprak Fiziksel Analizieri. Atatürk Üniv. Ziraat Fakültesi. Yaym No.143, $132 \mathrm{p}$.

Hancock, J. F., 1999. Strawberries. CABI Publishing, Wallingford, Oxon 0X10 8DE, UK. $237 \mathrm{p}$.

Jensen M. H., Collins W. L., 1985. Hydroponics vegetable production. Hort. Reviews, 7: 483558.

Kacar B., 1989. Plant Physiology. University of Ankara, Faculty of Agric. No. 1153, 323 p.

Oly mpious C. M., 1992. Soilless media under protected cultivation rockwool, peat, perlite and other substrates. Acta Hort. 401: 443451.

Özeker E., Eltez R. Z., Tüzel Y., Gül A., Önal K., Tanrýsever A., 1999. Investiga tions on the effects of different growing media on the yield and quality of strawberries grown in vertical bags. Acta Hort., 486: 409414.

Paydas S., Kaska N., 1992. Türkiye için Önemli olabilecek yabanci bazi çilek çeşitleri. Derim, 9 (2): 7179. 
